\title{
1. Fiscal institutions and budget balances
}

No one can be more appreciative of the advantages of the federal system than

I. I see it as one of the most potent arrangements there is for making men prosperous and free. (Alexis de Tocqueville, Democracy in America, 2004, vol.

1, Part 1, Chapter 8, p. 192)

In the democratic centuries that are about to begin, I think that individual independence and local liberties will always be a product of art. Centralization will be the natural form of government. (Alexis de Tocqueville, Democracy in America, 2004, vol. 2, Part 4, Chapter 3, p. 796)

By minimizing the role of local government, there will simply be less scope for locals to seek fiscal assistance; they will have less capacity to raid the fiscal commons. But this can amount to throwing the baby out with the bath water. Central governments, as we all know, can themselves exploit their monopoly position. (...) The challenge is rather one of determining the kinds of institutions that can accommodate fiscal decentralization so as to realize the political advantages and economic gains from local control, while avoiding the potentially distorting and destabilizing effects that can result from soft budget constraints. (Wallace Oates, Toward $A$ Second-Generation Theory of Fiscal Federalism, 2005, p. 362)

\subsection{MOTIVATION}

Why are some countries struggling with fiscal crises while others maintain stable government finances? To understand the dynamics of today's fiscal and debt crises, it serves to go back to previous cases. One region where fiscal instability was a major obstacle to reaching overall macroeconomic stability in the past is Latin America. There is little argument that past crises in that region have, to a considerable extent, been home grown and that inefficient policy processes invited structural imbalances. Fiscal mismanagement became evident when the Latin American debt crisis broke out in 1982 and again, in a series of financial crises, during the late 1990s and early 2000s.

At the end of the 1980s, the international community made a large effort 
under the Brady Plan ${ }^{1}$ to assist highly indebted countries (measured by the share of public debt in national income) in bringing down their debt levels. Yet, international crisis management was not sufficient as an instrument to get countries on a sustainable track. Domestic impediments to reaching macroeconomic stability remained in many countries. When the Mexican crisis spilled over to other Latin American countries in 1994, fiscal imbalances came to the fore once again, becoming a major concern for governments, among other reasons, because the International Monetary Fund (IMF) emphasized the importance of fiscal balance adjustments in continued consultations with debtor countries. Nevertheless, as is often the case, when times became better with growth rates resorting to pre-crisis levels soon after, structural problems became of less concern to governments. During the economic recovery of the following years, only a few governments made it their priority to address the remaining institutional problems and undertake reforms. When a second wave of external macroeconomic shocks reached the Southern Cone economies, after the Asian crisis in 1997 and the Russian default in 1998, the repercussions were soon felt across the region (Reinhart and Rogoff 2009).

Fiscal imbalances in Latin America figured prominently once more in the business pages of international newspapers at the end of the 1990s and the beginning of the 2000s after the region's two largest economies, Brazil and Argentina, experienced a toxic mixture of current account, currency and public financial crises. Throughout 2001, the year of the Argentine sovereign default, public debt ratios and government deficits in most of Latin America rose to alarming levels, threatening the stability of the region as a whole. However, not all countries were affected by the external shocks in the same way. While some countries suffered large-scale crises in government finances, bringing governments to (the brink of) default on external liabilities and leading them to abandon fixed exchange rate systems, others were less affected.

Compared to the situation in the mid-1990s, we see by the late 2000s profound improvements in government finances on average. Fiscal balances have been recovering for more than half a decade since 2003 and did not deteriorate to alarming levels throughout the Global Financial Crisis (GFC). Given the region's long history of pro-cyclical government finances, this may be seen as a success. Also, a large number of governments decided to use increasing tax revenue during the economic upswing of the 2000s to reduce public debt to more sustainable levels. Nevertheless, large crosscountry differences remained in the Latin American and Caribbean region following the financial market crises of the early 2000s, considering that the gap between the country with the highest budget surplus, Chile, and the country with the highest deficit, Nicaragua, was roughly 12 percent of 
GDP around the middle of the 2000s, according to the IMF's Government Finance Statistics (GFS). Figure 1.1 depicts how strongly Latin American countries differed in their average performance over the full period under consideration. Yet, as shown by the deficit data in Figure 1.1, there is also significant variation in performance within countries over time.

The different effects of macroeconomic shocks or, more precisely, the different capacities of Latin American governments to act on external shocks, open up an important research question. Given that countries experienced largely the same external macroeconomic shocks and financial conditions and followed similar policy recommendations by international organizations, why are they so different in their macroeconomic and, in particular, their fiscal performance? After the Asian crisis and the Russian default, emerging market economies were suffering from similar credit constraints following from the risk aversion of financial market participants. Likewise, they were affected by similar trade shocks resulting from a slowdown in international demand for their exports in 1999. If these macroeconomic factors cannot explain the differences in outcomes, it seems timely to consider some alternative institutional explanations.

One argument that immediately comes to mind is that governments were unable to adjust to external shocks in due time because they were too constrained by inflexible exchange rate regimes (currency pegs) (see e.g. Clark and Hallerberg 2000, Garrett 2000, Feldstein 2002, Calvo et al. 2003, de la Torre et al. 2003). Yet, the degree to which fiscal accounts were stabilized and brought back on a sustainable track differs even in countries that followed similar trends in exchange rate policies. For example, both Argentina and Brazil relied on fixed exchange rate regimes, aiming to stabilize their economies before this policy was changed in reaction to major economic shocks towards the end of the 1990s. In the course of economic recession and speculative attacks on their currency regimes, both countries were forced to abandon their pegs and shifted to a currency float. But they differed fundamentally in their approach to fiscal consolidation. In the end, they also differed in their macroeconomic performance.

If the answer is neither to be found in the realm of macroeconomic conditions nor in the area of exchange rate regimes, we may be best advised to look at other institutional and political determinants. In the present study, several of the 'usual suspects' drop out right away by logical reasoning. For example, differences in the regime type (presidentialism) and common distinctions between electoral systems (proportional representation versus majoritarian systems) cannot explain the variance depicted in Figure 1.1, given that they are more or less constant across the cases in my sample. In contrast, by looking at the difficulties with initiating macroeconomic reforms in Latin America in the past, we may find that veto players certainly 


\section{Average Nominal Budget Balance-to-GDP Ratios (1990-2006)}

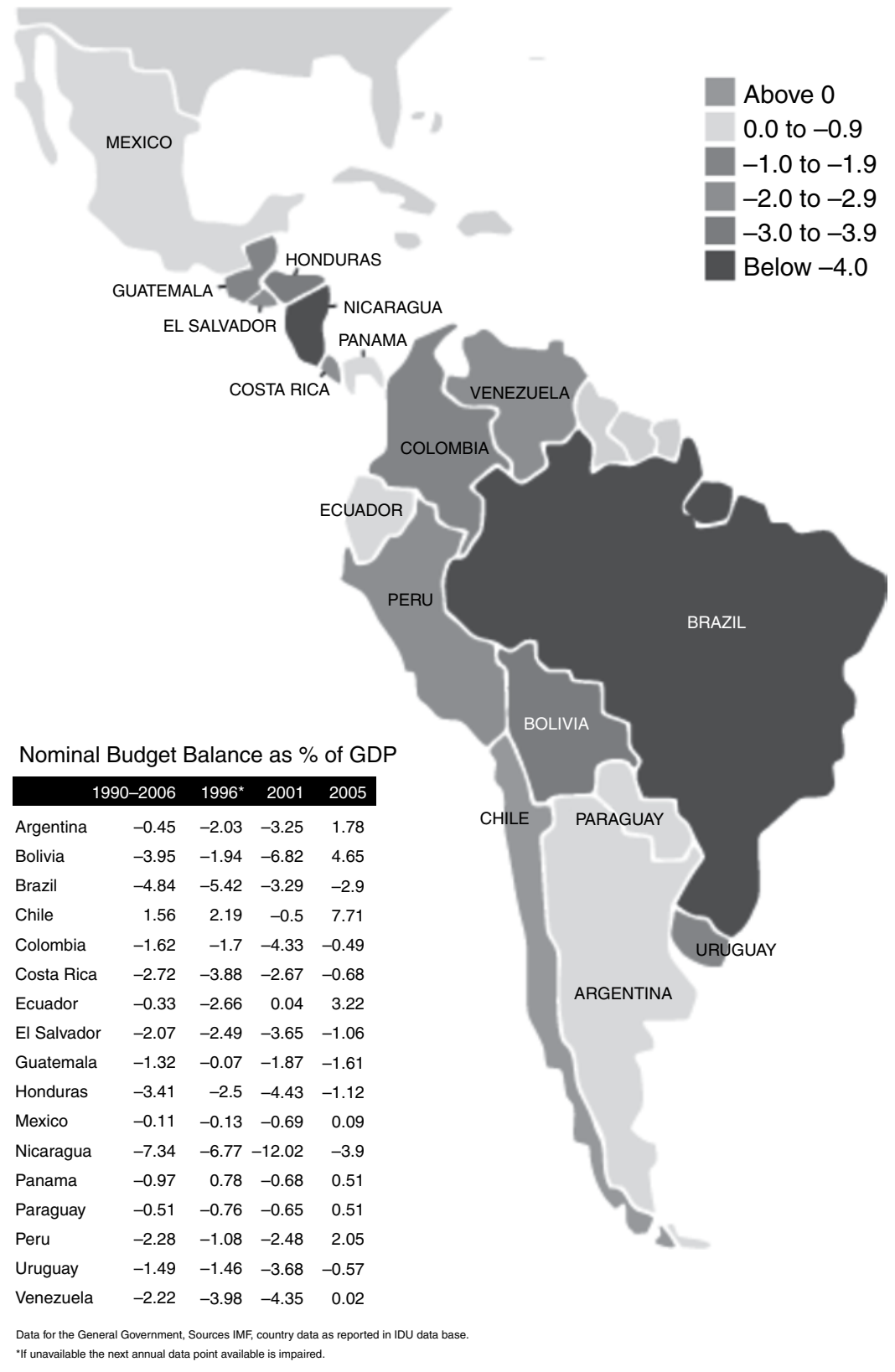

Figure 1.1 Fiscal imbalance in Latin America 
mattered. Indeed, veto player theory may serve scholars in understanding why and under what circumstances leaders were able to move from a 'negative' to a 'positive' fiscal policy equilibrium. However, acknowledging that the number of ideologically dispersed veto players affects leaders' ability to change their policy position does not provide a satisfactory answer as to why deficit financing and over-borrowing by public entities became so prevalent in the first place in some countries but not in others.

\subsection{INSTITUTIONAL EXPLANATIONS OF FISCAL IMBALANCE}

\subsubsection{Fiscal Imbalance as a Common Pool Resource (CPR) Problem}

The present study builds on previous political economy research in arguing that the incidents of extremely negative fiscal outcomes apparent in the data can best be understood as a consequence of a collective action problem - that is, the problem of coordinating fiscal policy among different rational, self-interested budget actors in a way that leads to optimal outcomes for the general public. Under the assumption that these budget actors are not constrained by any rules or other budget constraints, individual politicians are likely to succeed in maximizing their share of what constitutes the 'common pool resource', the national tax base, while keeping their contributions as low as possible. As a result, we often observe government spending bias and eventually growing budget deficits and unsustainable borrowing levels.

\subsubsection{Budgetary Institutions}

To solve the above-described problem, generally referred to as the common pool resource (CPR) problem, governments may choose to take measures leading to a 'hardening' of budget constraints. As was suggested by a significant amount of institutional literature in economics and political science, we may find that hard budget constraints by and large follow from a more hierarchical control by a 'central budget authority' with the clear objective to provide long-term stability of government finances (von Hagen 1992; for a comprehensive overview, see Persson and Tabellini 2000, and Hallerberg et al. 2009b). Next to hierarchical institutions, a large number of contributions discuss the value of implementing fiscal targets also referred to as a 'statutory approach'- to harden budget constraints. Without doubt, the latter assumption would seem to depend on whether budget actors are able to credibly commit to a sanctioning mechanism, 
guaranteeing that fiscal rules are respected. In the budgetary institutions literature, the term 'centralization' is generally employed to describe a stronger coordination of fiscal policies, with the aim of reducing the negative externalities of individually rational free-riding behavior, whether this is achieved through implementing more 'hierarchical procedures' or through a 'statutory approach'. The more budget decisions are centralized in that sense, the more is government oversight over revenue and expenditure expected to improve. Ideally, this leads to reducing spending bias and a list of related problems, including the threat of growing fiscal deficits and public debt. As has been emphasized in a number of more recent contributions in that literature, for reforms of budgetary institutions to facilitate improved fiscal policy coordination, what may be more important than the distinction between delegation and statutory approaches is the way in which a specific approach harmonizes with the underlying characteristics of the political and electoral system (Hallerberg and von Hagen 1999, Hallerberg 2004, Hallerberg and Marier 2004, Hallerberg et al. 2009a, 2009b).

Critics of the above-described budgetary institutions approach often emphasize the difficulty of isolating the suggested independent effect of budgetary centralization on fiscal balances from the effect of other unobserved - factors. When budgetary institutionalists point to recent cases of successful stabilization, such as Brazil since the early 2000s, questions immediately arise whether we can attribute the fiscal improvement to institutional reforms or whether it is best explained by favorable external economic conditions benefitting governments in the entire region (Izquierdo et al. 2008). ${ }^{2}$ To be able to provide a more nuanced picture of the potential relationship between institutional reform and macroeconomic outcomes, more empirical analysis seems necessary. Before we get there, however, it may serve to look at some stylized facts from a historical example that will illustrate the theoretical meaning of hard budget constraints.

\subsubsection{A Historical Example of Budget Process Centralization: Early 20th Century USA}

Are institutional reforms that centralize fiscal authority in the hands of the executive an effective way of improving fiscal outcomes? If so, are there historical examples that allow us to evaluate the effect of institutional change over a longer time horizon, providing evidence that centralized institutions can successfully be 'locked in' and serve as binding constraints on budget policies long after they have been established?

To find out if reforms of fiscal institutions can lead to long-term improvements in fiscal outcomes, it may serve to look at an early 20th century 
example from the USA. With the founding of the Bureau of the Budget $(\mathrm{BOB})^{3}$ under the auspices of the Treasury Department through the Budget and Accounting Act of June 10, 1921, President Warren G. Harding (1921-1923) took a bold step to centralize fiscal authority. ${ }^{4}$ President Harding's reform aimed at strengthening executive control over the previously less structured budget process, with the ultimate goal of reaching fiscal stability and taking control of the public debt that had risen to a historical peak following war-time military expenditure (Berman 1979, p. 3). ${ }^{5}$ And so, the BOB was founded as a new agency with the authority to assemble, revise, reduce or increase the budget proposals of government departments and agencies. While reform proposals had circulated for at least a decade, the political window of opportunity to take action on fiscal matters opened suddenly during a short but harmful economic recession that lasted from the beginning of 1920 until mid-1921. Americans experienced the recession as a painful shock after the general economic upswing following the end of World War I. Given that, under the Gold Standard, the US government lacked the monetary instruments to react promptly to the upcoming recession in 1920, the government found itself in the uncomfortable position of having to control fiscal deficits or lose access to financial markets. Choosing the first option, the US government embarked on a path of fiscal consolidation. Following the new legislation, government expenditure fell from a peak of 29 percent of GDP in 1919 by more than 10 percentage points until 1922. From then on until the Great Depression in 1929, government size relative to GDP stabilized at around less than 12 percent. Looking at historical fiscal data, it becomes clear that the course of fiscal consolidation taken under Harding was followed by a significant improvement in the fiscal stance. ${ }^{6}$ But was this policy sustainable?

Looking at the 1930s, we observe, at first, expansive fiscal policies, following increasing numbers of budgetary actors involved in household decisions as a consequence of the New Deal policies advanced during the presidency of Franklin D. Roosevelt (1933-1945). Although initially eager to create new government agencies with the objective of stimulating the economy, the Roosevelt administration soon tried to recentralize budget control. It was Roosevelt himself who tried in 1934 to recentralize government control over the budget process. To do so, he elevated the BOB to a cabinet-level agency, however kept under the auspices of the presidential office. These institutional changes were followed by several budget cuts, effective in 1935, 1937 and 1938. From a historical perspective, the founding of the $\mathrm{BOB}$ - later renamed the Office of Management and Budget marks an important turning point for the USA. To date, the office remains an essential resource for presidents targeting areas where spending could be reduced and revenue raised. ${ }^{7}$ While some may view the creation of the 
agency as 'original sin', allowing presidents to pass contested fiscal adjustment programs through Congress more readily, there is little doubt that the agency helped the US government to build a reputation over many decades as a sovereign debtor able to act on fiscal problems in due time when necessary, even in times of strong political polarization.

As shown in the historical example, centralizing a country's budget processes can inspire a virtuous cycle, leading to a significantly improved fiscal stance. A possible causal mechanism leads from institutional centralization to changed incentives for budget actors, facilitating fiscal policies that are oriented towards the long-term sustainability of government budgets. All things being equal, the strengthening of budget constraints, together with improved transparency, should therefore lead to improved fiscal stability.

There are also, of course, more critical accounts of increased centralization. What they have in common is a critical view of all-too-powerful central governments. To be able to control the latter, power needs to be checked not merely by distributing decision rights to other actors on the national level (i.e. power sharing between different branches of government), but also by dividing fiscal authority along the vertical axis, i.e. by providing subnational governments with fiscal authority. ${ }^{8}$ For good reasons, these arguments have made their way into actual policy recommendations to developing countries by the World Bank and other international organizations (for an overview, see Tanzi 1996, World Bank 2000 and UNDP 2005). Based on such recommendations, governments have followed vertical decentralization policies in the transition to democracy. A concern is that governments may have followed such recommendations more or less blindly, at least with regard to the potentially negative budgetary consequences of allowing for more fiscal decentralization. Looking at the Latin American and Caribbean region, we observe, for instance, an increase in vertical decentralization - measured as subnational expenditure over total government expenditure - from an average of 13.1 percent in 1985 to 19.3 percent around the mid-2000s, according to research by the Inter-American Development Bank (Daughters and Harper 2007). ${ }^{9}$

\subsubsection{Vertical Fiscal Decentralization and the CPR Problem}

In the institutional literature, we find both proponents of fiscal federalism and critics that warn of potential destabilizing effects. In one branch of the literature, decentralizing fiscal authority along the vertical axis of government is described as beneficial for overall fiscal stability, for several reasons. ${ }^{10}$ First, as pointed out by Brennan and Buchanan $(1977,1980)$ in their influential theoretical contribution, decentralization strengthens 
stability through its capacity to limit the exploitative fiscal policies of 'Leviathan' governments. Second, as was demonstrated by Oates (1972) in his 'decentralization theorem', vertical decentralization may improve allocative efficiency because subnational governments are better able to match the tastes of their constituencies with the public goods they provide. We should thus see less wasting of public resources under more decentralization. In the long run, this should enhance the stability of subnational finances and hence reduce the risk of fiscal imbalance on the aggregate level. ${ }^{11}$

According to Brennan and Buchanan's (1977) Leviathan model, which sees over-arching and intrusive central governments as a key impediment to stable government expenditure, a strategy that empowers decentralized budget actors allows the latter to control expenditure by the center. Beyond that effect, however, vertical decentralization may not only serve to control central government expenditure but also to control local-level government expenditure. Along the lines of Tiebout's (1956) earlier argument, competition among subnational governments may be seen as a viable mechanism for limiting the growth of government on the local level, ${ }^{12}$ where local governments are under the scrutiny of local constituencies with an interest in fiscally responsible management of their local contributions. Although the empirical evidence for both hypotheses above remains mixed for industrial countries, the notion that decentralizing fiscal authority induces smaller government is taken up in several follow-up contributions focusing more on the developing and transition countries (see the discussion in Oates 1985, Rodden 2006, and Prohl and Schneider 2009). ${ }^{13}$ For example, the argument that competition among vertically decentralized governments enhances fiscal stability at the local level is revived in the 'market-preserving federalism' literature (Qian and Weingast 1995, Weingast 1995). There, the central question is how economic innovation and growth can be stirred in an environment in which over-arching centralist governments, for example in the former Eastern Bloc countries, pose a major obstacle to allocative efficiency. In such a context, local budget authorities are ascribed a superior role in guaranteeing a better match between the tastes of constituencies and the provision of public goods. A related argument states that (vertical) decentralization of fiscal authority in low-income countries is crucial to ensuring that pro-poor policies actually reach the targeted groups and segments of the population (Pauly 1973, Bird and Vaillancourt 1998, World Bank 2000, UNDP 2005). ${ }^{14}$

Notwithstanding the popularity of decentralization policies, in particular among development scholars, a significant amount of research on the effects of fiscal federalism has questioned the notion of the 
predominantly welfare-improving effects of vertical fiscal decentralization. For example, Prud'homme (1995) warns of the potential dangers of decentralization, which increases the number of policy makers with incentives to exploit the 'fiscal commons'. In this scheme, subnational budget actors are likely to shift the burden of financing local spending programs to the central level. ${ }^{15}$ This critique is taken up by a number of policy studies as well as in broader empirical analyses that have identified common pool resource problems on the subnational level, following from increased decentralization in expenditure and borrowing rights. Unless contained in due time, subnational CPR problems are found to pose a threat to the overall stability of government finances (Tanzi 1996, Ter-Minassian 1997a, Burki et al. 1999, Stein 1999, Treisman 2000, Wibbels 2000, Rodden 2002, 2003, 2006, Rodden and Wibbels 2002, Rodden et al. 2003).

An illustrative negative example is Argentina before the sovereign default in 2001, where fiscal profligacy on the part of the provinces repeatedly put overall government stability at risk (Braun 2006). Looking at the past history of subnational fiscal instability in Brazil, before the government of President Fernando Henrique Cardoso implemented institutional reforms at the end of the 1990s, we find similar evidence of subnationally induced fiscal imbalances at the national level. The same patterns of subnational CPR problems as drivers of both subnational and eventually central-level fiscal imbalance, were also identified in a series of cross-country studies by Rodden (2006). The latter represents a major contribution to the empirical literature on fiscal imbalance in the region and beyond, combining case studies with large $\mathrm{N}$ cross-country timeseries analyses, looking at OECD and non-OECD countries over time. A main conclusion is that fiscal imbalance is most likely where subnational governments are simultaneously free to borrow and highly dependent on central-level transfers. Similar factors drive subnational and, subsequently, central-level deficits. These results are in line with other studies, pointing to the budget-undermining relationship between subnational fiscal indiscipline and increases in general government expenditure and debt (e.g. von Hagen and Eichengreen 1996, Treisman 2000, Wibbels 2000, Rodden 2002, 2003, Rodden and Wibbels 2002, Rodden and Eskeland 2003). The reason why the decentralization of budget control along the vertical axis leads to imbalances is generally seen in the increasing CPR problems following from a larger number of unconstrained budget actors drawing on the national tax base to finance local-level public goods. Although I side with Rodden (2006) on the potential fiscal destabilization following vertical fiscal decentralization, I come to a different conclusion on the mechanism that explains this outcome. 


\subsection{TOWARDS A NEW FRAMEWORK OF ANALYSIS}

\subsubsection{The Conditional Effect of Vertical Fiscal Decentralization, Depending on Horizontal Centralization}

The institutional literature introduced above provides considerable evidence suggesting that by decentralizing fiscal authority on different levels, policy makers may have enhanced the risk of fiscal imbalance. This was explained in a parsimonious and convincing model - the so-called common pool resource (CPR) model. Accordingly, any move towards decentralizing fiscal authority increases the number of budget actors with incentives to free-ride on the national tax pool, leading to an overuse of the common tax pool. A number of follow-up problems, affecting overall stability, are likely to evolve. Contributions from the budgetary institutions strand of the literature show empirical links between decentralization of the budget process on the national level and fiscal performance indicators, including the size of government, deficits and public debt, both in absolute terms and relative to the economic strength of an economy. Budgetary institutions have been found to affect both levels of and changes in fiscal variables. Also, authors were able to show that the effectiveness of certain types of budgetary institutions depends on the ways in which they harmonize with underlying political institutions.

However, one aspect that has not yet received enough attention is the question of how budgetary institutions at the central level of government can help to reduce subnational-level free-riding on the common tax pool. Although it was argued by a significant body of fiscal federalism literature that vertical decentralization can create instability, affecting the central level in the long run, the budgetary institutions branch of the literature has, by and large, kept subnational budget actors out of the analysis. How can we explain that choice? Most authors are concerned primarily with fiscal instability in countries that are committed to a no-bailout doctrine with regard to subnational government units (e.g. the USA). Where nobailout clauses are the norm and local governments are controlled by functioning markets for government debt, national-level policy makers should care less about the fiscal activities of subnational governments because the center cannot - and will not - be held responsible for subnational fiscal crises. However, as the more recent fiscal federalism literature has pointed out, the 'no-bailout assumption' may have to be relaxed in a context where subnational governments are highly dependent on transfers and where the latter have been - for a long time - free to finance their deficits by increasing borrowing (Rodden 2006). Such seems to be the reality in the countries analyzed here. Given that in these - and perhaps in other - cases, 
subnational budget making and fiscal responsibility are indeed connected to central government more strongly than is acknowledged in the budgetary institutions literature, it seems important to scrutinize how changes in central-level institutions influence subnational budgetary decisions.

This being said, we also find little mention of the role of central-level budget institutions in the fiscal federalism literature. Here, the focus is almost exclusively on local-level causes of instability. However, leaving the central-level institutional context out of the picture may bias results. My aim here is to propose a new way of thinking about the effects of decentralizing fiscal authority. Along the lines of both types of literature presented above, I argue that decentralization of fiscal authority along the vertical axis bears risks for overall fiscal stability. However, my point is that the extent to which vertically decentralized fiscal authority creates imbalances depends on the general strength of budgetary institutions at the central level.

A significant amount of research suggests that vertical decentralization can, under certain circumstances, reduce the stability of national government finances. The question is how or through what mechanism we should think that fiscal behavior on the subnational level turns into a risk for the overall fiscal stability of a nation. One obvious way in which subnational fiscal imbalance may affect overall stability is by creating liabilities for the nation as a whole. Subnational deficits and accumulated public debt at the lower levels of government may simply add to whatever fiscal problems exist on the national level, making central government the 'lender of last resort' for the undisciplined local budget actor. In the chapters below, I submit a different view of central-subnational fiscal relations. We should only see imbalances, stemming from subnational fiscal indiscipline, if budgetary institutions at the national level appear to be weak. Specifically, that means that where the national-level budget process is only weakly coordinated and lacking transparency, subnational fiscal actors are much more likely to over-spend and accumulate deficits. This is because soft budget constraints at the national level signal soft enforcement of fiscal discipline to the local level, affecting the political calculus of subnational leaders and, in much likelihood, their spending behavior. Hence, I expect the degree of budget process centralization at national level and the behavior of subnational budget actors under vertical fiscal decentralization to interact.

Figure 1.2 summarizes the potential causal mechanism that $I$ have in mind. The first arrow leading from 'horizontal decentralization' to fiscal stability reflects my first hypothesis, arguing that a less coordinated horizontal-level budget process directly affects budget stability by shaping incentives for national-level budget actors to free-ride on the common 

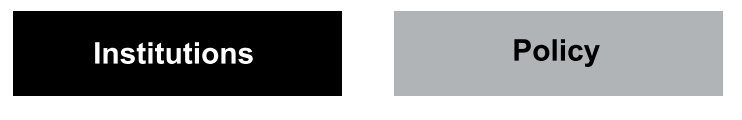

Welfare Measure

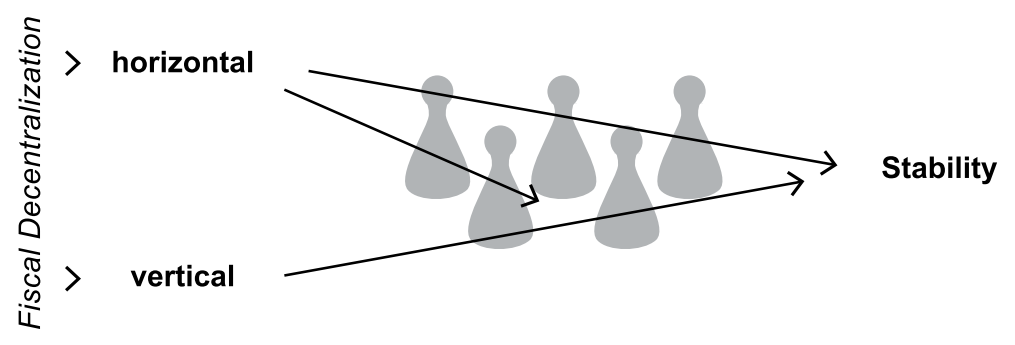

Allocation

Redistribution

Figure 1.2 Horizontal and vertical fiscal decentralization of decision-making authority

tax pool. In addition to the direct effect, the two other arrows indicate that subnational fiscal behavior interacts with national budgetary institutions. Under vertical fiscal decentralization, subnational budget actors face stronger incentives to reap the benefits arising from local authority over-expenditure and 'export the costs' to the nation. However, I argue that central-level budgetary institutions are capable of conditioning this potentially destabilizing effect of vertical decentralization.

\subsubsection{Methodological Approach}

To the best of my knowledge, no study has tried to analyze vertical decentralization and national-level budgetary institutions in a single framework. Yet, a more comprehensive empirical approach, integrating both aspects, seems necessary to get to the roots of fiscal imbalance and macroeconomic instability, based on insights from previous research on budget imbalances in Latin America. In the empirical analysis below, I therefore start by analyzing the effects of horizontal decentralization on fiscal imbalance, relying on different research methods, combining graphical analysis of crosscountry data with comparative case studies on institutional changes (or lack thereof) in Argentina and Brazil between 1990 and 2006. My analysis 
ends in 2006 at the advent of the Global Financial Crisis, beginning with the 'Subprime Crisis' in the USA a year later, which inaugurated a period of exceptional turbulence in the international financial system. Focusing on the Latin American region comes at the cost of building one's conclusions based on observations of a relatively small number of countries, especially given that the data availability narrows the sample size down to 15 countries. On the upside, this regional sample allows me to assume relative unit homogeneity as countries share a fair amount of historical experience and cultural norms. Another advantage is that I automatically control for a number of alternative political and institutional explanations of fiscal imbalance (e.g. democracy, presidentialism, electoral systems). With the graphical analysis of cross-sectional data, I aim to identify common patterns, regarding the effect of horizontal decentralization on fiscal stability. Extensive case study analysis allows me to focus on institutional change over time, bringing to the fore also the political circumstances of reform endeavors.

Relying on additional country- and subnational-level data for two countries that are not available for the larger sample, I highlight in the case studies how central government reforms and subnational fiscal behavior interact. The choice of the two countries follows from a mostsimilar systems design. Argentina and Brazil share largely similar country characteristics, regarding economic structure, the degree of openness in trade and of financial market integration. Furthermore, their political and institutional systems share many characteristics. Both are presidential democracies with a federalist tradition, including a high degree of vertical fiscal decentralization. Yet, both countries varied over the time period studied in the way they organized fiscal decision-making processes, on the national level and between the central and lower tiers of government. For my case studies, I draw on first-hand information gathered in over 30 semistructured expert interviews with policy makers in Latin America. During research stays in Argentina and Brazil, I interviewed former members of those core economic teams that were in office during the governments of President Carlos Menem (1989-1999) and President Fernando de la Rua (1999-2001) in Argentina, and during the government of President Fernando Henrique Cardoso (1995-2002) in Brazil. Additional background information comes from interviews with country experts at the International Monetary Fund, the World Bank, the IADB and with private sector experts. Finally, I rely on archival data from the IMF and other academic sources on the fiscal and macroeconomic crises in both countries. Evidence from the case analysis allows me to develop my theoretical model further, incorporating new findings that may, as suggested by Lieberman (2005), allow me to engage in improved theory-driven large $\mathrm{N}$ analysis at later stages. 


\subsection{ALTERNATIVE EXPLANATIONS FOR BUDGET IMBALANCES}

\subsubsection{Fragmented Policy Making in Proportional Representation (PR) Systems}

After laying out my own argument above, I proceed by reviewing some of the most widely discussed alternative explanations for fiscal imbalance in the political economy literature. First, there is a widely shared belief, going back to two influential articles by Roubini and Sachs (1989a, 1989b), that more fragmented (coalition) governments are more likely to be associated with fiscal imbalance than single-party governments because the former incur a greater risk of political instability. To support their claim, the authors initially presented their analysis of growth in government expenditure and in public debt, respectively, in OECD countries between 1960 and 1985, concluding that the difficulties that several developed countries faced in reducing high deficits in the post-Bretton-Woods era resulted from fiscal management problems under 'fractionalized' coalition governments. However, it should be noted that empirical evidence on the relationship between coalition government and fiscal instability does not clearly support the argument made by Roubini and Sachs. ${ }^{16}$

Coalition governments generally come about as a result of proportional representation (PR) electoral systems, whereas majoritarian voting rules are usually associated with single-party governments. Following a widely quoted article by Alesina and Drazen (1991), a broad literature revolves around the question of whether PR systems lead to more severe political gridlock, thereby incurring macroeconomic instability, including fiscal deficits. Alesina and Drazen (1991) refer to this as a 'war of attrition' game between governments and their political opponents. In these models, rational self-interested leaders postpone their decisions, waiting for the other side to move first. As a consequence, crucial policy decisions are likely to be delayed, worsening an already existing problem. Unlike the more general claim about coalition governments made earlier by Roubini and Sachs (1989a, 1989b), the 'war of attrition' model, pointing to the relationship between PR systems and fiscal instability, is supported by many empirical studies. However, this finding does not necessarily conflict with my argument that CPR problems are at the root of fiscal imbalance. ${ }^{17}$ To be sure, all of the countries in my sample have electoral systems that involve some degree of PR. It may therefore seem rather implausible that proportional representation by itself could explain the - sometimes considerable differences in fiscal stability between countries across the region at hand and across time. 


\subsubsection{Veto Players}

Related to the first argument about macroeconomic imbalances under coalition governments, we may find that larger numbers of - ideologically dispersed - veto players explain why fiscal adjustment is often missing where and when it seems most needed. Following Tsebelis (1995, 2002), it could be argued that the larger the number of such veto players, the higher is the status quo bias and, hence, the potential for reform delay and, consequently, for fiscal instability. Empirically, this relationship seems to be rather robust. ${ }^{18}$ Yet, while there is little doubt that higher numbers of ideologically dispersed veto players are likely to reduce the maneuvering space for a government, it is not self-evident that status quo bias leads to worse fiscal outcomes. ${ }^{19}$ It could also serve to 'lock in' policies that are conducive to fiscal stability. Whether we actually observe instability due to a delay in necessary fiscal adjustment or quite to the contrary, a government's stern conviction to stick to adjustment thus depends on the status quo ante and needs to be determined on a case-by-case basis.

\subsubsection{Electoral and Partisan Cycles}

All of the different alternative explanations discussed so far focus on a 'policy delay' or 'gridlock' channel, providing reasons why fiscal restraint is not implemented. Other research has focused more on the failure to design budgetary institutions in such a way that 'vote-maximizing' politicians will face few incentives to over-exploit the common tax pool to begin with. To take a real-life example, we are, as political observers, well aware of the fact that, unless they are constrained by budget rules, politicians are likely to increase government expenditure on local public goods around election time, targeted at creating the support of certain groups of voters. Since Nordhaus' (1975) landmark contribution, economists and political scientists have stressed the importance of so-called political business cycles (PBCs) for public expenditure, deficits and debt. ${ }^{20}$

A different but related approach, advanced by Hibbs (1977) and Tufte (1978), states that fiscal imbalance is more likely to appear under left-wing party incumbency. So-called partisan cycles in government are thought to lead to spending increases, given the different redistributive priorities that are rooted in leftist political ideology. In these approaches, left-wing governments, as opposed to centrist or right-wing governments, are seen as more prone to increase public spending and less willing to apply fiscal cuts in transfer schemes. However compelling one may find the argument that partisan cycles explain large differences in fiscal outcomes, it appears that, empirically, there is no clear-cut support for the argument, 
neither in studies looking only at OECD countries nor in those drawing on larger samples, including non-OECD countries. Partisan cycles have not only been questioned by a range of empirical studies on OECD as well as non-OECD countries. ${ }^{21}$ Clearly, the partisan-cycle argument would appear difficult to keep up in the context of Latin America in the past two decades, where left-wing governments are connected with all kinds of economic policy preferences and where the fiercest advocates of Washingtonconsensus-type macroeconomic reforms are to be found among leftist (or supposedly left-wing) governments (Campello 2015).

\subsection{LOOKING AHEAD}

In the chapters ahead, I start out by developing my theoretical approach to fiscal imbalance in emerging market nations, based on earlier insights from the institutional literature. Arguing that horizontal-level budget institutions interact with subnational fiscal behavior under different degrees of vertical fiscal decentralization, I proceed in several steps: in Chapter 2, I first return to the literature on budgetary institutions before I go deeper into fiscal federalism theory and review different predictions about the effects of decentralizing fiscal authority. Based on this review, I suggest a new model that combines previous approaches (Chapter 3).

In line with the previous literature, I submit that (a) decentralization of the budget process on the national level creates CPR problems, which are at the root of persistent fiscal deficits, and (b) the decentralization of budget authority along the vertical axis incurs additional CPR problems and fiscal indiscipline on the local level, creating liabilities for general government finances. However, I depart from the existing literature in the following way, providing novel insights on the interplay of subnationaland national-level fiscal discipline: according to my suggested theoretical framework, the negative effects of vertical fiscal decentralization depend to a large extent on a contextual factor, which is the degree of budget process decentralization on the national level or what I refer to as 'horizontal decentralization'. Thus, I suggest that vertical decentralization and horizontal decentralization interact, assuming that the decisions that subnational leaders make are influenced by institutional centralization on the central level. In Chapter 3, I discuss my argument in more detail and present the working hypotheses that serve as a guiding line for the two comparative case studies on Brazil and Argentina (chapters 5 and 6) and may eventually provide a basis for the future cross-sectional time-series analysis.

In Chapter 4, I analyze the fiscal imbalances in Latin American and 
Caribbean countries between 1993 and 2006. Given the lack of comparable data for earlier periods, my graphical analysis is restricted to data from two waves of surveys on the strength of budget institutions in the region. In chapters 5 and 6, I discuss in detail how national-level institutional reforms (or lack thereof) in Brazil and Argentina changed incentives for policy makers, both on the national and subnational levels. In Chapter 7, I summarize my key findings from comparing both cases. The evidence that I find confirms to a large extent the patterns that I detect in the graphical analysis for the larger sample of Latin American and Caribbean countries. In both cases, I find strong support for my argument that subnational CPR problems lead to severe fiscal problems for the country, on condition of a loose central-level budget process and low transparency at the national level. However, the situation changed significantly over time in the case of Brazil where a gradual reform process, beginning in 1996/97, induced stronger budget coordination and enhanced transparency at the horizontal level. I argue that in both countries, governments initially relied on 'market discipline' to impose hard budget constraints on local governments. However, given that the ambitious no-bailout doctrine soon turned out to be incredible, inviting creditor 'moral hazard', the hoped-for marketdisciplining effects were essentially undermined. In the case of Brazil, where subnational governments experienced in 1997 the third fiscal and debt crisis in under 10 years, the federal government engaged in reforms of its budgetary institutions, leading to a centralization of fiscal decisionmaking power at the national level, increasing budget transparency and strengthening controls over the borrowing activity of subnational governments and other government agencies. What we observe in Brazil at the end of the 1990s can be summarized as a shift from a strategy that relies mostly on 'market discipline' to a 'regulatory approach'. In Argentina, we observe no comparable shift to a long-term-oriented strengthening of budgetary institutions at the horizontal level. Subnational fiscal problems increase to worrisome levels after 1997, creating pressure on the federal government to provide a bailout. At a point in time when the financial markets (and international financial organizations) were becoming more and more sensitive to any signs of policy gridlock and political uncertainty, the federal government was strongly constrained in its ability to implement fiscal adjustment in the amount needed to stay on top of its mounting debt-servicing obligations. The government's inability to come up with a macroeconomic strategy to manage the growing sovereign debt problem, including a plan to reduce subnational deficits and stop subnational debt expansion, contributed significantly to the sovereign debt crisis, culminating in the default declaration in December 2001.

At the beginning of this chapter, I submitted that (fiscal) decentralization 
has important virtues and, as de Tocqueville (2004) noted early on, it seems well founded to say that it contributes crucially to democracy in America and elsewhere. Yet, as the same author argues in a later chapter of his treatment of political and economic life in the early USA, decentralized fiscal authority also carries risks for economic and political stability under democratic government. Much in line with Oates (2005), I argue that governments need to set up binding central constraints on budget actors in order to deliver the benefits of vertical decentralization. Ideally, such institutions deter the raiding of fiscal commons, both by politicians on the national and subnational levels of government. By implementing strong central-level budgetary institutions, governments commit to hard budget constraints and to more transparency of the budget process, fundamentally changing incentives for subnational budget actors. I will return to this point in the last chapter (8) and discuss it in light of my empirical results. In the latter sections of Chapter 8, I include a list of policy recommendations based on the analysis of fiscal institutions carried out below. As a social scientist, I am aware of the potential pitfalls of drawing conclusions from limited empirical samples. That is why my final remarks should be seen more as an endeavor to provide some 'rules of thumb' for political actors and decision makers, rather than as a (fruitless) attempt at any kind of prognosis as to where things are heading in certain regions or countries in the years to come.

\section{NOTES}

1. Since the outbreak of the Latin American debt crisis in 1982 in Mexico, following quickly rising interest rates combined with low commodities prices undermining many debtor countries' ability to service their liabilities, a series of debt negotiations with private creditors has taken place. For most countries, the negotiated debt rescheduling and restructuring agreements still fell short of providing governments with enough 'breathing space' to repay their outstanding debts. First implemented in 1989, the Brady Plan - as a coordinated debt restructuring framework - thus depended on a growing understanding among creditors that many of the loans provided to Latin American governments over the 1980 s would never be entirely repaid, and that some form of substantial debt relief was necessary to allow countries to get back on track with regard to economic growth. To this end, the Brady Plan was designed to contain the following three elements: (1) an agreement between external private creditors and debtor governments that lenders would accept debt reduction in exchange for improved collateral; (2) government agreement to improve macroeconomic stability by implementing a set of crucial macroeconomic reforms; (3) new debt instruments to be introduced that improved the tradability of government debt in international financial markets (e.g. the so-called Brady bonds). Although each country's debt negotiations with its international creditors were held separately, leading to a unique debt agreement, each Brady restructuring included choices from a common 'menu of options', leading to a debt reduction involving similar debt instruments, such as the exchange of bank loans for bonds of equal face amount with fixed, below-market interest rates (par bonds) or loans 
for lower face-value bonds with market-level, floating interest (discount bonds). The Brady Plan, judged by most financial experts as a successful policy solution, enabling many countries to regain access to international capital markets, lasted from 1989 - with the onset of negotiations on Mexico's sovereign debt - until 1994 when the last agreement, between Brazil and its external creditors, became operational. Eighteen countries signed a Brady agreement with their creditors over that period. According to Cline (1995), the typical Brady deal led to a reduction of 30-35 percent of a country's debt.

2. Giambiagi and Ronci (2004), taking a mid-way position regarding fiscal improvement in Brazil, argue that while the fiscal adjustment in the second half of the 1990s was possible due to an increase in revenue rather than through a reduction in expenditure, the fiscal responsibility legislation (FRL) and the implementation of fiscal constraints were necessary to preserve fiscal stability. Alston et al. (2009, p. 77) come to a similar conclusion, pointing to the disciplining effect of the FRL in Brazil, which they find to extend beyond the national level, arguing that the FRL in Brazil 'does in fact constrain the behavior of the state governments, contributing greatly to achieving and maintaining fiscal sustainability'.

3. The Bureau of the Budget (BOB) was, later on, under the presidency of Richard Nixon (1969-1974), renamed the Office of Management and Budget and granted further autonomy.

4. Kiewiet and McCubbins (1991, p. 166) note that while the Budget and Accounting Act built largely on 'practices that had already been implemented' prior to World War I, it sufficiently 'redelegated the authority to formulate appropriations requests and compile the budgetary data to the newly created Bureau'.

5. At the same time, however, the simultaneous creation of the Independent Audit Office under the same Act was to assure us that presidential control over government finances was monitored by an independent agency outside of government.

6. According to historical data series available through Proquest Statistical Insight, the US government secured rapidly growing budget surpluses until the end of the 1920s, with the budget outcome growing by 46 percent between 1921, the year of the Budget and Accounting Act, and 1927 when a turning point was reached.

7. Pfiffner (1979, quoted in Kiewiet and McCubbins 1991, p. 166) notes that the creation of the Bureau of the Budget marks the 'beginning of the domination of the budgetary process by the institutionalized presidency'.

8. One obvious starting point for these approaches is the following: while the centralization of decisions increases fiscal stability, it very likely has effects on two other main functions of fiscal policy that are not, for practical reasons, covered to the necessary extent in the study at hand and that have been identified by Musgrave (1959) as effective allocation and redistribution functions. This means that I forgo a more detailed discussion of the allocative function at this point and will only make reference to approaches in that literature where an argument can be made that determinants of allocative efficiency are also likely to have an impact on stability. Likewise, I leave the general discussion on redistributive concerns, summarized by Beramandi (2007), among others, to future research.

9. Daughters and Harper (2007) report that the median for expenditure decentralization in Latin American and Caribbean countries was 8.3 percent in 1985, compared to 13.7 percent in 2004. Based on their data, the largest increase in expenditure decentralization took place between the early and mid-1990s, indicated by a shift in the sample median of 3 percent.

10. For a recent discussion on the effects of vertical fiscal decentralization on all three separate policy objectives - stabilization, allocation and redistribution - defined earlier by Musgrave (1959), see e.g. Fedelino and Ter-Minassian (2010, part 1).

11. Tiebout (1956) had advanced a similar proposition, however, based on the more restrictive assumption that in a world of freely moving households, tax payers would choose among different packages of public goods offered by communities, essentially allowing the latter to constrain local governments through a 'vote by the feet'. Based on these 
conceptions, we would likely see more accordance between revenue and expenditure, meaning that rather than posing a threat to overall stability, the latter should be improved through vertical decentralization.

12. In the following, I use the terms subnational government and local government interchangeably with reference to executives of the state or provincial-level executives and the local or community level.

13. One reason why the empirical evidence on the effect of vertical fiscal decentralization may be ambiguous, as Rodden (2003) notes, is that researchers were not using the 'right' empirical indicators, failing to control for a set of variables that may otherwise obscure the hypothesized relationship.

14. Comparing these arguments to the reality in developing countries, Bahl and Linn (1992) argue that allocation efficiency, described by Tiebout (1956) and Oates (1972), is likely to be conditional on a country's ability to reach a certain 'threshold of development'. In other words, before we think about how to better guarantee a perfect match of tastes and public goods, it would seem advisable to think about ways to guarantee some degree of economic development. On a more critical note, Wibbels (2000) presents strong empirical evidence that questions the welfare-enhancing effects predicted by Weingast (1995) and others in the context of developing countries that lack crucial economic and institutional pre-conditions for 'market discipline'. Wibbels (2000) concludes that greater vertical fiscal decentralization in non-OECD countries is more likely to significantly reduce governments' ability to adjust economically, as it increases domestic collective action problems. Tommasi (2006) finds the success of vertical decentralization to depend on an accountability that guarantees that electorates have control over public good provision by local governments, while Blanchard and Shleifer (2001), among others, point to the danger that a weak center could more easily be 'captured' by revenue-maximizing local leaders, undermining attempts to redistribute income to poorer parts of the population.

15. Earlier, Scharpf $(1979,1988)$ also emphasized the downside of multi-tiered (fiscal) governance in developed countries when it comes to changing the status quo of government finances and re-organizing fiscal relations between the center and its constituent units.

16. To be sure, several follow-up studies, using the same 'fractionalization' index, did not reach the same conclusions and largely rejected the empirical relationship presented by those authors. For an overview, see de Haan and Sturm (1997).

17. Persson and Tabellini (2000) provide an overview of theoretical models of the war-ofattrition type that are concerned with the failure to react to fiscal distress promptly, while Persson and Tabellini (2003) discuss an array of empirical contributions on the link between proportional representation (PR) systems and macroeconomic outcomes, concluding that PR systems are linked to larger government expenditure and deficits. In a comprehensive cross-country time-series analysis using data for 88 countries, the authors conclude that 'majority elections induce smaller governments, less welfare state spending, and smaller deficits than proportional elections' (Persson and Tabellini 2003, p.215). In a panel analysis of OECD countries (1970-1995), Kontopoulos and Perotti (1999) find confirming empirical evidence for the gridlock hypothesis.

18. Franzese (2002), in a comprehensive analysis of 21 OECD countries (1948-1997), provides robust empirical evidence confirming a negative relationship between the number of veto players and fiscal deficits.

19. As Franzese (2002, p. 48) points out, '(f)ractionalization and polarization produce inaction, and the impact of inaction depends on what would have happened under the status quo'. Indeed, if the relationship between the number of veto players and fiscal imbalance depends on the status quo ante, high fiscal deficits should only appear where public expenditure was high in the first place and where increasing veto players led to a preservation of high spending levels, even after the macroeconomic circumstances deteriorated. In a similar vein, with regard to inflation outcomes, Treisman (2000) argues "that additional veto players may "lock in" existing patterns of monetary policy whether inflationary or strict'. Hence, by saying that higher numbers of veto players 
cause policy inertia, it is not said that the outcome is higher inflation (fiscal deficit) but only that whatever the status quo ante looked like will prevail.

20. See Persson and Tabellini (2000) for an overview of theoretical models following Nordhaus (1975); Brender and Drazen (2005) and Kaplan (2013) provide more recent overviews. Recent empirical evidence on the effect of PBCs remains quite mixed, with some contributions questioning the role of political cycles in industrialized countries under increased financial globalization (Helleiner 1994, Mosley 2000, 2003). When we shift the focus to non-OECD countries, the evidence seems to be more supportive of the PBC hypothesis (Leblang 2002, Block and Vaaler 2004). However, regarding Latin America results are similarly mixed. Here, Nieto-Parra and Santiso (2009) find that general elections are associated with much greater changes to fiscal policy in Latin America than in high-income countries. They submit that the average primary balance declines by almost 0.7 percent of GDP during an election year, looking at a sample of 28 OECD and 19 Latin American countries between 1990 and 2006. Kaplan (2009), who looks at PBCs around 122 elections in 16 Latin American countries between 1961 and 2006, concludes that under the condition of increased financial opening and countries' prior shock experience with hyperinflation during the 1980s, incumbents in the post-1990s era rely on inflationary manipulation of the economy much less frequently than before. Hence, Kaplan (2009) attributes the 'demise of the PBC' largely to the fact that politicians in crisis-ridden Latin American countries not only react to market pressure but also to the changed macroeconomic priorities of constituencies.

21. Franzese and Jusko (2006, p. 13) show, in a meta-study of the empirical literature, including OECD and non-OECD countries, that partisan cycles have a significant impact on several macroeconomic outcome variables, with the strongest effects present in studies of the size of government, revenue and spending policies. To be sure, however, Franzese and Jusko (2006, p. 14) also emphasize that 'naive left-deficit, right-surplus arguments (...) have least support' of empirical data. This finding is in line with several recent empirical studies providing evidence that markets remain sensitive to left-wing electoral victories, particularly in emerging market economies that are characterized by high political uncertainty (Leblang and Bernhard 2000, Leblang 2002, Martínez and Santiso 2003, Block and Vaaler 2004, Vaaler et al. 2006). Campello (2008) provides a model of optimal taxation under capital mobility that accommodates both (left-wing) divergence and convergence hypotheses. Accordingly, investors tend to flee a country when a left-wing government with a redistributive agenda replaces a right-wing government. Changes from right- to left-wing government evoke strong investor reactions, particularly in emerging economies. However, in anticipating increased capital flight during elections, left-wing incumbents in an unstable environment are likely to back down on their initial redistributive agenda, particularly in countries that have recently experienced a currency crisis. The empirical analysis of portfolio investors' behavior during 125 elections, both in industrialized and low-income countries, largely confirms the predictions of the model that investors are sensitive to information about redistribution (Campello 2008). Furthermore, Campello shows, in data for 89 Latin American elections between 1982 and 2006, that left-wing candidates in countries experiencing currency crises prior to the election campaign, are those most likely to back down from their initial redistributive agenda. 